
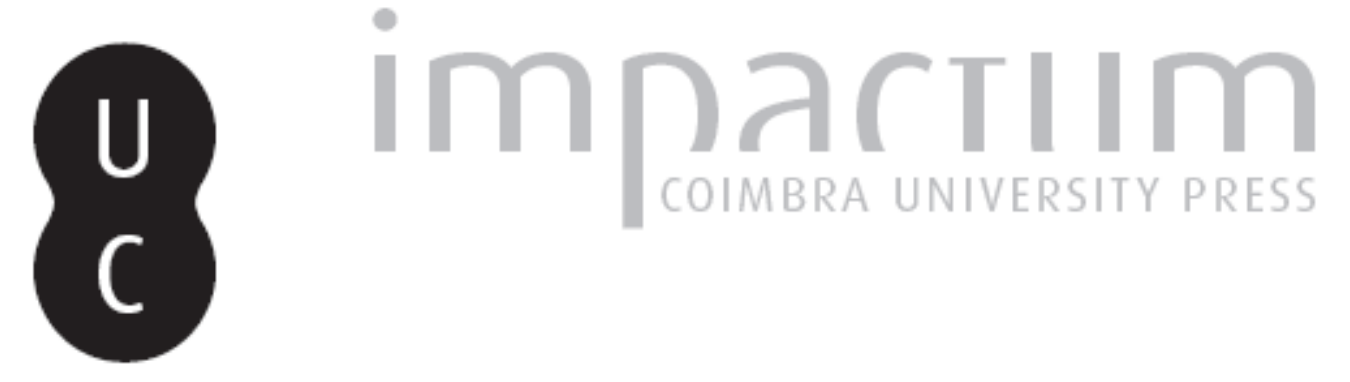

The role of culture in the regional development process: Sibiu - European Capital of Culture 2007

Autor(es): $\quad$ Stoica, Alina; Chirodea, Florentina Publicado por: Centro de Informação Europe Direct de Aveiro; Centro de Estudos
Interdisciplinares do Século XX

URL

persistente:

DOI: $\quad$ DOI:http://dx.doi.org/10.14195/1647-6336_12_8

Accessed : $\quad$ 26-Apr-2023 09:20:30

A navegação consulta e descarregamento dos títulos inseridos nas Bibliotecas Digitais UC Digitalis, UC Pombalina e UC Impactum, pressupõem a aceitação plena e sem reservas dos Termos e Condições de Uso destas Bibliotecas Digitais, disponíveis em https://digitalis.uc.pt/pt-pt/termos.

Conforme exposto nos referidos Termos e Condições de Uso, o descarregamento de títulos de acesso restrito requer uma licença válida de autorização devendo o utilizador aceder ao(s) documento(s) a partir de um endereço de IP da instituição detentora da supramencionada licença.

Ao utilizador é apenas permitido o descarregamento para uso pessoal, pelo que o emprego do(s) título(s) descarregado(s) para outro fim, designadamente comercial, carece de autorização do respetivo autor ou editor da obra.

Na medida em que todas as obras da UC Digitalis se encontram protegidas pelo Código do Direito de Autor e Direitos Conexos e demais legislação aplicável, toda a cópia, parcial ou total, deste documento, nos casos em que é legalmente admitida, deverá conter ou fazer-se acompanhar por este aviso.

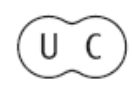


DEBATER

A EUROPA

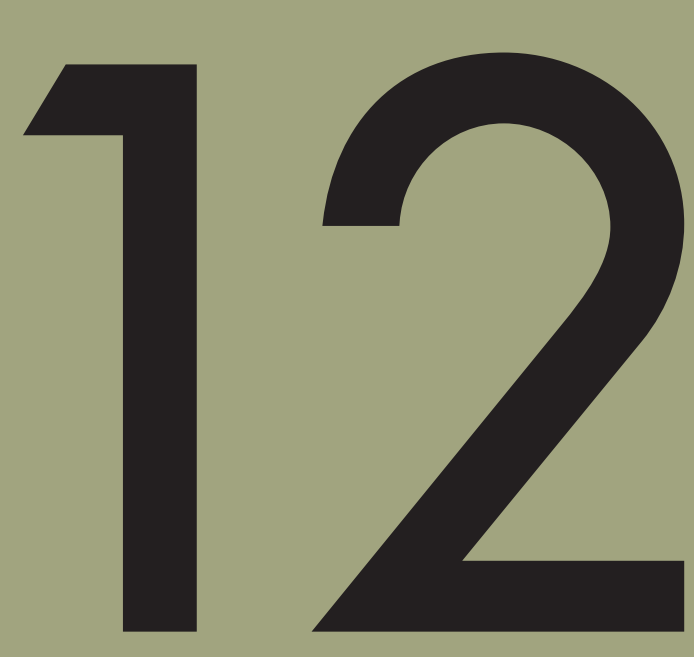

jan-jun 2015

POLITICAS REGIONAIS DA UE

EU REGIONAL POLICIES 


\title{
The role of culture in the regional development process. Sibiu - European Capital of Culture 2007
}

\author{
Alina Stoica \\ Lecturer, PhD at DIRES University of Oradea, Romania \\ Director of Jean Monnet Module "The Cultural Diplomacy at the East and West of European Union-an \\ essential element of the Integration process" \\ E-mail: astoica@uoradea.ro \\ Florentina Chirodea \\ Lecturer, PhD, Department of International Relations and European Studies \\ University of Oradea, Romania \\ E-mail: fchirodea@uoradea.ro
}

\begin{abstract}
In the recent years, an increased interest in the use of culture as an instrument of politics and economics has expanded and influenced regional development. This paper aims to highlight the ability of culture to generate wealth for the community, on the one hand, and on the other as a catalyst for sustainable economic recovery by developing innovative and creative sectors based on arts activities. We will, however, single out the city of Sibiu and implicitly the "European Capital of Culture", city that aims to highlight the richness and diversity of cultures in Europe, the contribution of culture to urban development, the increasing international profile of cities and a better image in the eyes of the inhabitants.
\end{abstract}

Keywords: European capital of culture, Sibiu, culture, regional development

The intensification of globalization has boosted EU policies towards strengthening cohesion between its component states. Among the measures taken we notice those aimed at regional development. It seeks "to boost and to diversify economic activities, stimulating investment in the private sector contribution to reducing unemployment and not ultimately to 
lead to an improvement in the living standards"1. This created a relationship of interdependence between the Community and the region whose aim is to improve long-term economy and the quality of life for all EU citizens, regardless of where they live. Expression of solidarity between the Member States of the European Union, regional development policies and cohesion policies direct most of the funds available to less developed areas ${ }^{2}$. They can thus exploit the full potential, leading to alleviate regional disparities existing between national and European levels ${ }^{3}$.

Regional development from an economic perspective "involves the use of resources (primarily local ones, but also national and international ones) to increase the overall competitiveness of the territory, increasing the adaptability of production and functional components to the needs of structural adjustment (for regional and national needs) and, ultimately, from a macroeconomic perspective, for reducing the disparities between different parts of the structure of national economic space"4. However, all these statements, generate a natural question: what are the factors, methods and means that can foster the development of a region and that can generate essential processes of change for the community in general? How can one place change the course of its evolution for the benefit of its inhabitants?

The specialty literature identifies a number of primary factors, on the one hand the production factors (capital, labor and resources), and on the other those that provide a favorable business climate (basic Infrastructure and accessibility, human resources and productive environment) $)^{5}$. They are also influenced by a number of secondary factors, "soft determinants" among which we single out: institutions, technology, innovativeness, enterpreneurship, internationalization, social capital, knowledge Infrastructure, culture, demography $\&$ migration, quality of place, and environment ${ }^{6}$. The formation and evolution of

\footnotetext{
${ }^{1}$, Regional development policies-concepts”.

See: http://www.mdrap.ro/dezvoltare-regionala/politica-de-dezvoltare-regionala

${ }^{2}$ HORGA, Ioan; BĂRBULESCU, Iordan Gheorghe; IVAN, Adrian - Regional and cohesion policy: insight into the role of the partnership principale in the new policy design. In Regional and cohesion policy. Oradea: Debrecen, 2011.p.5

3"Regional policy", European Commission, 2014, p. 3.

See: http://europa.eu/pol/pdf/flipbook/ro/regional_policy_ro.pdf

${ }_{5}^{4}$ DORIN, Jula, Regional Economy, Editura Estfalia, Bucureşti, 2002., p.35

${ }^{5}$ MARTIN, Ronald L. - A Study on the Factors of Regional Competitiveness, Report for the European Commission - Directorate General Regional Policy, p.1.

See also: http://ec.europa.eu/regional_policy/sources/docgener/studies/pdf/3cr/competitiveness.pdf, accesed in Aprilie, 15, 2014, p.35-36. Borozan Dula, „Regional Competitiveness: Some Conceptual Issues and Policy Implications." In Interdisciplinary Management Research, 2008, vol. 4,

http://www.efos.unios.hr/repec/osi/journl/PDF/InterdisciplinaryManagementResearchIV/IMR4a03.pdf, accesed September 1st, 2014

${ }^{6}$ MARTIN, Ronald L., op.cit., p. 35 -36
} 
these "soft" externalities is seen as being crucial in the dynamics of regions and cities. Moreover, in the recent years, there is an increased tendency to define and explain the regional competitive advantage by taking into account the cultural dimensions, along with the "hard" dimensions of the regional socio-economic environment.

Recent studies have shown that local cultural factors can considerably influence the ability of an area to generate wealth for the community, while being a catalyst for sustainable economic recovery by developing innovative and creative sectors based on arts activities ${ }^{7}$. On the other hand, culture is seen as a participatory factor to the democratization of the region. Most strategies developed by authorities who were aware of the role of the culture in regional development focus on the civic culture that allows for the expression of participatory democracy, the basic element of promotion and development of the social economy of that community and a precondition for increasing collaboration between the region with other regions or countries. Investing in culture brings many advantages in all sections of life for the community. Access to culture in a large extent changes the community attitudes, while improving the mental state of the population, which in turn increases personal motivation and self-esteem of the individual, thereby improving sociability, power and involvement of the settlement and, therefore, their standard of living, and also individual and collective responsibility in the production of goods and / or providing services. Adequate development of individuals, groups and communities can determine gaining independence from foreign aid $^{8}$. Moreover, for a well-functioning democratic governance in the region, individuals and groups must be animated by the interests of others, high levels of solidarity, trust and tolerance, cooperation skills ${ }^{9}$.

In this context, at the poles of regional growth, culture stands out among other factors, by its contribution to the creation of a local identity (aesthetic, artistic and literary values ${ }^{10}$ based on the preservation of cultural heritage, which in turn generates localization of investors and highly qualified human capital, a significant increase in tourism activities in the area, transforming cities into cultural "junctions" of their vecinities. Among the tools that the

\footnotetext{
${ }^{7}$ LAZZERETTI, Luciana - Creative Industries and Innovation in Europe. Concepts, Measures and Comparative Case Studies. S.1: Routledge, 2012, p.12.

${ }^{8}$ LOGHIN, Dina - "Participatory democracy-sense for social economy". See also: http://profitpentruoameni.ro/wp-content/uploads/2013/05/01-DEMOCRATIAPARTICIPATIVA_PRECONDITIE-PENTRU-ECONOMIA-SOCIALA.pdf

${ }^{9}$ MYERS, S. - Democracy is a Discussion. Civic Engagement in Old and New Democracies. Connecticut: The Handbook, Connecticut College, 1996, p. 7.

10 "Role of cultural values in society", published by Crissy Crys, 2011, p.2. See also: http://ro.scribd.com/doc/57779774/Rolul-Valorilor-Culturale-in-Societate\#scribd
} 
European Commission have created to solve the problems of urban and regional development there is the program called "European Capital of Culture", which aims to highlight the richness and diversity of cultures Europe, the contribution of culture to urban development, increasing international profile of cities and towns and a better image in the eyes of the inhabitants ${ }^{11}$. Since 1980, many cities have benefited not only from having a successful year, but also of a legacy of lasting socio-economic heritage ${ }^{12}$, culture thus proving its major contribution to change not only of the city but of the entire region. The media coverage at large of the area brings certain benefits in tourism development, an increased local interest in culture, greater social cohesion, strengthening local infrastructure and the dialogue between the community and local authorities ${ }^{13}$.

The selection process begins six years before receiving the title. The Member State designated as the host of the event publish a call for applications, through the Ministry of Culture. Cities wishing to participate in the competition must submit a Proposal for Consideration. The first stage is the preselection. A group of independent experts in the field of culture review the dossiers (admissions) on the basis of predetermined criteria, substantially reducing the number of cities that remain in the competition. The remaining cities must resubmit a more detailed application of their intention. "European Capitals of Culture are formally designated four years before the actual year. This long period of time is necessary for the planning and preparation of such a complex event" ${ }^{\prime 14}$.

Our interest in this study, focuses on the implementation of the European program for Sibiu, designated as European Capital of Culture in 2007, along with Luxembourg. The particular attention ${ }^{15}$ that the first and only, so far, Romanian city that received the title enjoyed is due not only to the celebration of European culture and civilization during a calendar year in a city on the border with eastern Europe, but also because the event coincided with the accession of Romania to the EU and has brought substantial benefits to the local

\footnotetext{
11 „European Capitals of Culture”. See also: http://ec.europa.eu/programmes/creative-europe/actions/capitalsculture_en.htm

${ }^{12}$ „Action regarding European capitals of culture".

See also: http://www.capitalaculturala2021.ro/ceac2021_doc_2_actiunea-privind-capitalele-europene-aleculturii_pg_0.htm

${ }^{13}$ IMMLER, Nicole L.; SAKKERS, Hans - Programming Europe: European Capitals of Culture: rething the role of culture. In Journal of European Studies, vol 44 (I), 2014, p.5.

14 "European Capitals of Culture". See also: http://ec.europa.eu/programmes/creative-europe/actions/capitalsculture_en.htm

${ }^{15}$ RICHARDS, Greg; ROTARIU, Ilie - "The Impact of Cultural Events on Tourism Development: Sibiu - the European Cultural Capital.” In Annals of the „Constantin Brâncuşi” University of Târgu Jiu, Economy Series, Issue 1/2013, “Academica Brâncuși”, Târgu Jiu: Publishing House, 2013, p.6.
} 
community. Researchers and evaluators who have studied the subject are unanimously in agreement that the impact of the program in Sibiu was important both at regional and European levels, and the results are relevant for the development of the program during the budget year 2007-2013. Nationally, the title obtained in 2007 by Sibiu is presented as a model of development through culture, expressions like the "Sibiu model" or "the success of Sibiu" are often used in public speeches ${ }^{16}$. We do not refer only to the specific objectives of the program (increasing the international profile of the host city, long-term cultural development, attracting international visitors, foster a sense of pride and confidence in the local community, growth and expansion of the local audience for culture, improving social cohesion, improving cultural and non-cultural infrastructure, developing collaborative relationships with other European regions and promote cultural cooperation, creativity and innovation) but also to the effects of the economy and development of the region adjacent to Sibiu. In the following, we will cover the results of sociological research, studies and reports issued by various Romanian and EU specialists in 2007 and in the years that followed, in order to bring arguments in support of the above ideas, and to evaluate the usefulness and sustainability of the program called "European Cultural Capital" in regional development.

\section{SIBLUX2007}

On 10 February 2004 an official mission arrived in Sibiu from Luxembourg to prepare the visit of 30 March of the Grand Duke Henri and of the Grand Dutchess Maria Teresa. During talks between Mayor Klaus Johannis and Guy Dokendorf, Director General of the Luxembourg Ministry of Culture, Sibiu was invited to partner up with Luxembourg in the European Capital of Culture program ${ }^{17}$. The choice was presented as an "unusual openness to cultural collaborations with potential for future continuity" ${ }^{\text {"18 }}$, Sibiu and its surrounding areas being known as multicultural areas "in which Romanian, German, Hungarian and Roma cultural valences dilute and mutually reinforce each other"19. It was thus met the overall

\footnotetext{
${ }^{16}$ OANCA, Alexandra, - Governing the European Capital of Culture and Urban Regimes in Sibiu. MA Thesis, Budapest: Central European University, Department of Sociology and Social Anthropology, 2010, p. 4.

${ }^{17}$ Ibidem, p. 20

${ }^{18}$ VASILIU, Florica; DRAGOMAN, Dragon - "Cultural policies and the affirmation of identity. Luxembourg and the Grand Region-Sibiu. European cultural capital 2007” in Romanian Sociology, vol. VI, no. 2/2008, Editura Polirom, Iași, 2008., p.33.

${ }^{19}$ LUCA, Sabina Adina - "The role of the programme Sibiu 2007-European capital of culture in socio-economic urban development." In Quality of Life, vol. XX, no. 1-2/2009, Romanian Academy Press, Bucharest, 2009. p. 171.
} 
objective of the most popular European cultural initiative, that was to value the richness of cultures of the Member States, their common traits, to promote mutual understanding between EU citizens and fostering a sense of belonging to a community ${ }^{20}$.

In terms of program management, the idea was part of the Commission's strategy of granting, starting with 2007, the title of Cultural Capital simultaneously to two cities, one from the West and one in Central and Eastern Europe. The success of the project presented is particularly important because, when accepting (2004), Romania was in the process of preaccession. New frontiers were penned on the map of Europe, with culture as the main tool to promote community values and principles, but also to report to alterity ${ }^{21}$.

The proposal presented by the urban coalition was based on the idea that Europe is a continent of regions ${ }^{22}$, the main theme being migration, not only as a contemporary phenomenon, but also as a historical one that links the two cities that are located thousands of miles away. From this point of view, choosing Sibiu was motivated by the idea of the common origins of the Saxon settlers and the residents of the Grand Duchy, Luxembourg being considered by some experts as "the homeland of origin of the Transylvanian Saxons" or rather "the only autonomous political entity and easily identifiable in all germanofobie space as home to medieval settlers". Language studies began in XVIII - XIX centuries, demonstrating similarity between German dialects spoken in Transylvania and Luxembourg, or similarities between urban architectural styles were other arguments used by the Romanian and Luxembourg authorities in favor of the myth of common ancestors ${ }^{23}$.

Another common feature of the project is the involvement of adjacent areas of the two cities, the Greater Region, composed of four areas (Lorraine, Rhineland-Palatinate, Saarland and Walloon Region) and Sibiu respectively ${ }^{24}$. The complexity of the proposal involved a close collaboration between local authorities in Luxembourg and Sibiu, with a massive support received from the government of the Grand Duchy in the heart of Europe and from Romanians, especially that the regions involved belong to different local government units. Despite initial skepticism of the European Commission, the jury appreciated the complementary nature of the proposed events, and on 27 May 2004 voted unanimously in

\footnotetext{
${ }^{20}$ COSMA, Smaranda; NEGRUSA, Adina; POPOVICI, Cristina, - "Impact of Sibiu European Capital of Culture 2007 event on country tourism." In MASTORAKIS, Nikos E.; JHA, Manoj; MLADENOV, Valeri; BOJKOVIC, Zoran; KARTALOPOULOS, Stamatios (eds.) - Recent Advantage in Cultural Heritage and Tourism. S.1.: WSEAS Press, 2009., p. 68.

${ }^{21}$ LUCA, Sabina-Adina, op.cit, p. 171

${ }^{22}$ COSMA, Smaranda; NEGRUSA, Adina; POPOVICI, Cristina, op. cit., p. 68-69

${ }^{23}$ VASILIU, Florica; DRAGOMAN, Dragoş, op.cit, p. 33 - 34 and Alexandra Oanca, op.cit., p. 26

${ }^{24}$ OANCA, Alexandra, op.cit, p. 24
} 
favor of the SIBLUX 2007 program. Among the strong points it was mentioned ${ }^{25}$ : multiculturalism ${ }^{26}$, reinforced by the logo chosen for Sibiu - "City of Culture. City of cultures"; the European nature of the application; proposed strategy for implementation; sustainability of the project; unique partnership ${ }^{27}$ between the two cities. Other arguments in favor of Sibiu, this time, referred to ${ }^{28}$ : numerous partnerships and collaborations developed with other cities (Landshut, Rennes, Klagenfurtm, Deventer etc.); great experience in organizing cultural events (jazz or film festivals); western urban atmosphere expressed particularly by the quality of life, lifestyle and the value system of local community.

The overall objective of the proposed urban partnership, promoting local cultural values, is added with the concrete specific objectives tailored to the needs of each city. Thus for the Greater Region, already known as an area with strong economic development, the focus was on promoting it as a cultural region ${ }^{29}$, while for Sibiu, the proposed strategy aimed at economic, cultural, image, social and urban regeneration objectives ${ }^{30}$. Given the complexity of SIBLUX2007, especially regarding the Transylvanian city, all partners focused primarily on designing and then on implementing the program. The association "Sibiu European Cultural Capital 2007" was created, a structure in which the entire cultural program was

\footnotetext{
${ }^{25}$ COSMA, Smaranda; NEGRUSA, Adina; POPOVICI, Cristina, op.cit, p. 69-70 and VLADENCO, Florian "How the project of Sibiu European capital of Culture 2007 was born", interview with Klaus Weber Iohannis. In Vacanțe și Călătorii.

${ }^{26}$ A study made by specialists at "Lucian Blaga" University of Sibiu in 2006, highlights the city's multicultural character well anchored in local collective mentality, the first argument being the lack of reaction of the majority ethnic Romanian population (being of $96.8 \%$, comparing to $1,3 \%$ Germans, $1,1 \%$ Romas and $0,3 \%$ Hungarian) to the insistent references of the city's foundation by the colonists who had left the catchment areas of the Rhine, Moselle and Meusia.The same Orthodox majority (90.6 percent\%, from 3.3\% Greek-Catholic, $1.7 \%$ Roman Catholics, Evangelical Lutherans $1.6 \%$ and $0.8 \%$ Protestants) shall designate among the personalities of the city Baron Samuel von Brukenthal (15.3\%), and contemporary Klaus Johannis (71,3\%) at the time mayor of the representative of the German minority.See: Florica Vasiliu, Dragoș Dragoman, op.cit, p. 34 - 35

${ }^{27}$ The relations of cooperation between Luxembourg and post-Communist Romania began with the Organization of The Days of Romanian Culture in the capital of the Grand Duchy, April 1993. The event, which was attended by academics and representatives of Sibiu, was followed, a year later, by signing of an agreement between the two states concerning cooperation in the field of culture, education, science and sport. As a result of this agreement, in 1994 is ianugurated in Bucharest, "Pierre Werner" Center for Studies and Documentation, Romania-Luxembourg, under the high patronage of the Romanian Academy, in the presence of the Grand Duke and the Minister of culture, who, on this occasion, visited the city of Sibiu. In May 1998, it was opened SibiuEuropean Confluence Conference works, organized by the Ministry of culture under the high patronage of the President of Romania and with the financial support of UNESCO, Pierre Werner- President of the Luxembourg Government and honorary Henricot Schoepges Erna-Culture Minister in the same Government, have received the title of honorary citizens of the city of Sibiu. A year later the Romanian authorities assigned the Government of the Grand Duchy a building with an architecture resembling the Luxembourgish Centre houses for various common cultural projects. In 2004 the House was the seat of Luxembourgish institutions: Cultural Centre, Consulate of Luxembourg Grand Duchy of Luxembourg, the European Institute of Itineraries or team of researchers responsible for the compilation of The Dictionary of Saxon Dialects in Transylvania.See: Alexandra Oanca, op.cit, p. 27 - 29

${ }^{28}$ COSMA, Smaranda; NEGRUSA, Adina; POPOVICI, Cristina,, op.cit, p. 70

${ }^{29}$ OANCA, Alexandra, op.cit, p. 24

${ }^{30}$ RICHARDS, Greg; ROTARIU, Ilie, op.cit., p. 6
} 
developed and which coordinated the entire project. The Management Committee, supported by an advisory artistic committee and a Management Office with administrative functions, had the primary task of maintaining a close collaboration between the cultural network of Sibiu and Europe ${ }^{31}$. Through the 337 projects approved 2062 events were organized, diversified as artistic style and for different tastes, covering most sectors of art: theater, painting, music, film, dance, literature, architecture and contemporary art and gastronomy. The partnership with the Grand Duchy of Luxembourg resulted in 40 joint projects, demonstrating the European nature of the project. The total number of those who proposed projects was 301 cultural operators, public and religious culture, public performances and concerts, public education, cultural centers, cultural institutes of foreign embassies in Romania, embassies, NGOs national and European publishers, individuals, honorary consulates abroad and companies. Sibiu European Cultural Capital 2007 program was under the patronage of the President of Romania and was conducted in collaboration with the Municipality of Sibiu, Ministry of Culture and Sibiu County Council ${ }^{32}$.

\section{Implementation of "Sibiu European Capital of Culture 2007"}

The amount of funding allocated only for cultural projects was 13.4 million euros (8.2 million allocated by Sibiu City Hall to 215 projects, 450,000 euro from the County Council for 21 projects, Sibiu European Capital of Cultural 2007 Association funded two projects with 7,500 euro, from the Ministry of Culture was allocated a total of 3.4 million for 99 projects and the European Commission funded 1.4 euro for the events closure) $)^{33}$. The promotion campaign received a budget of 1 million euro and was held under the platform "Normal. Sibiu". The creative concept was intended to bring "a new vision of the role and presence of art and culture in a postmodern social context, young and uninhibited." The campaign makers wanted the campaign to present a city " 815 years young, an everyday living expression of the merger of cultures" to a target audience of 50 million people, of which $75 \%$ in urban areas, mostly young ${ }^{34}$.

\footnotetext{
${ }^{31}$ COSMA, Smaranda; NEGRUSA, Adina; POPOVICI, Cristina, op.cit, p. 70

${ }^{32}$ Official site of Sibiu CCE 2007 Programme, „Balance sheet of Sibiu European capital of Culture 2007”, http://www.sibiu2007.ro/ro3/bilant.htm, accessed January 7, 2015

${ }^{33}$ LUCA, Sabina-Adina, op.cit, p. 173

${ }^{34}$ IOANID, Doina „How prepared is the city of Sibiu to be European capital of culture in 2007” in Aletheea, no. 342/octomber 2006, http://www.observatorcultural.ro/Cit-de-pregatit-e-Sibiul-sa-fie-capitala-culturalaeuropeana -in-2007*articleID_16329-articles_details.html, [7.01.2015].
} 
The figures above are strictly the budget for cultural objectives - about $10 \%$ of the total initial budget of 43 million euro, which included financing costs related to the restoration of monuments of the city, cultural and urban infrastructure. According to official records, this budget, calculated for the period 2005-2007, was supported by cultural operators (7.3 million euro), the Ministry of Culture (21 million euro), Sibiu City Council (13.2 million euro) and Sibiu County Council (1.5 million). Other amounts were allocated for the rehabilitation and expansion of the airport (60 million euro, of which 11 million from the state budget) and to improve the region's infrastructure (6 million euro allocated from the state budget) ${ }^{35}$. Moreover, since 2002 there had been a steady increase in the local budget, with a significant peak in $2007^{36}$. The main expenses targeted the rehabilitation of 40 streets and main roads, the renovation of the three central markets, the restoration of the historic center, airport expansion and modernization, provision of equipment and stages for shows, rehabilitation of Gong Theatre and Thalia Hall ${ }^{37}$.

It goes without saying that this strategy could not succeed without substantial support from the government, which beside budgetary allocations started out a number of activities to promote Sibiu at European and international levels. One such event was organized in February 1999 by the Ministry of Culture in collaboration with the Chamber of Commerce and Industry of Romania and the Hanns Seidel Foundation. The seminar "Sibiu - Economic Rehabilitation through Culture" presented a thematic documentary material to ambassadors, representatives of foreign cultural institutes, Culture Ministers, representatives of the World Bank, UNESCO and the European Union, directors of the most important German companies present in Romania. Another state contribution to the success of the program was the issuance of the decree by which the city was declared area of national interest. Thus it was created the framework to showcase local historical and cultural resources in order to "transform the regional and local area in a target for economic growth and regional competitiveness" ${ }^{, 3}$. One consequence of these measures was the inauguration in the same year of the HQ for German Economic Club Transylvania in Sibiu, which acted as a forum for ideas and business opportunities for German, Austrian, Dutch and Swiss business people. In early 2000 the

\footnotetext{
${ }^{35}$ COSMA, Smaranda; NEGRUSA, Adina; POPOVICI, Cristina, op.cit, p. 71 - 72

${ }^{36}$ The budget for the year 2002 was expected to lie at the level of 21,3 million euros in 2003, it increased to 27.6 million euros, before moving in 2006 to reach 78.5 million euros, and in 2007 at 89,9 million. Sabina-Adina Luca, op.cit, p. 174

${ }^{37}$ Ibidem, p. 174-175 and Florian Vladacenco, op.cit., http://www.vacantesicalatorii.ro/modules/revista/articole /articol.php?artID=1809, accesat în 7.01.2015

${ }^{38}$ OANCA, Alexandra, op.cit, p. 27 - 31
} 
German Society for Technical Cooperation open offices in Sibiu too, contributing to the rehabilitation of the historic center and supporting local authorities in managing urban regeneration. In the period 2001 - 2003, industrial parks were open in Sibiu or in the surrounding areas, where foreign-owned firms operate ${ }^{39}$.

The event "Sibiu European Capital of Culture" opened on January 1, 2007, in the presence of President Traian Băsescu and Prime Minister Călin Popescu - Tăriceanu through a symphony concert and a series of art events and fireworks in the Market Square of Sibiu, event that was attended by over 40,000 people. During the year, major national and international cultural events were held in Sibiu. We refer to: TIFF, best known Romanian film festival, which opened in June with Cristian Mungiu's "4 Months, 3 Weeks and 2 Days", winner of the Palme d'Or; International Festival "George Enescu", with 6 concerts held in September; the MTV Music Awards Romanian Edition held in the Market Square; UNITER Awards Gala held in the Multipurpose Hall in the center of Sibiu; concerts by the Vienna State Opera and La Scala Milan; "Radu Stanca" International Theatre Festival; "Artmania" Rock Festival; “Sibiu. Dance. Festival” Dance Festival; Goran Bregovic's and Julio Iglesias' live performances; European Ecumenical Assembly. The year ended with several classical music concerts, supported by "Virtuosi" Chamber Orchestra from Bucharest and Sibiu State Philharmonic, folk concerts by People Radio Orchestra, Cindrelul Ensemble - Youth of Sibiu and a parade with the most popular bands Romanian. ${ }^{40}$

\section{Impact on local community and indicators for regional socio-economic} development

Investment and organizational efforts were, firstly, a major impact on the local community. A sociological study conducted in 2007-2011 by Greg Richards and Ilie Rotariu provide serious arguments in this regard. Thus the interviews of a sample of 170 people from Sibiu city and the surrounding areas, sample representative for the main groups of stakeholders (cultural operators, travel agencies and tours operators, banks, media, hotels,

\footnotetext{
${ }^{39}$ Ibidem, p. 33 - 39

${ }^{40}$ CERBAN, Mădălina - FOCUS: Sibiu-European capital-an investment of 50 million euros and one million tourists, 29 Novemeber 2007, http://www.mediafax.ro/main-story/focus-sibiu-capitala-europeana-o-investitiede-50-de-milioane-de-euro-si-un-milion-de-turisti-1067240, [7.01.2015].
} 
restaurants, business organizations) ${ }^{41}$ showed year after year some views, complemented by comments of journalists from local and national press:

- The image of medieval fortress, with historic architecture and atmosphere was much improved by the high-class cultural events organized, which led to increased visibility of Sibiu. In a short time the most famous city in Romania after Bucharest - Sibiu proved that the Romanian cultural act and Sibiu cultural act, in particular, may be at the same level with the European one ${ }^{42}$. The thus gained notoriety at the national, European and international levels ${ }^{43}$ made the city "something to be proud of" and Romania's image has benefited due to the feeling that "something good can be done, of quality and appreciated"44;

- The urban regeneration process, besides the fact that it demonstrated the ability of the industry, has positively influenced the local community and the residents by "spending more time in the center of Sibiu" where they have the opportunity to meet "people from different corners of the world" sites still open, the citizens of Sibiu foresee a "modern and clean city, paying respect to cultural heritage and stylish, with interesting places and full of freshness" ${ }^{\text {,46; }}$

- The role of local authorities in the development and success of the project was assessed favorably by locals, noting the municipality's involvement in fundraising and the efficient funds management for the community ${ }^{47}$. Nationally, the stakes of winning an important symbolic and image capital used by the central authorities to dismantle a cliché and to demonstrate that

\footnotetext{
${ }^{41}$ RICHARDS, Greg, ROTARIU, Ilie op.cit, p. 6 - 7

${ }^{42}$ MAZILU, Mirela, "Romania, Tourism and Culture - Major Drivers of Regional Attractiveness." In MASTORAKIS, Nikos; MLADENOV, Valeri et al (eds.) - Recent Researches in Mechanisc. S.1.: WSEAS Press, 2011.p. 283

43 Sibiu, the European capital of culture status in 2007, has been ranked by the British newspaper "The Guardian" as No. 9 among the top "50 fabulous locations all over the world", being overtaken New York and London. Also, according to some assessments made by CNN and the BBC, Sibiu is among the top ten tourist destinations in the world. See: Sorin Ilieșiu, Ion Bondrea (coord.), Sibiu- Regional Capital. Objective arguments, „Lucian Blaga” University Press, Sibiu, 2013, p. 13 și Mădălina Cerban, op.cit, http://www.mediafax.ro/mainstory/focus-sibiu-capitala-europeana-o-investitie-de-50-de-milioane-de-euro-si-un-milion-de-turisti-1067240, [7.01.2015].

${ }^{44}$ RICHARDS, Greg; ROTARIU, Ilie, op.cit, p. 6

${ }^{45}$ Ibidem

${ }^{46}$ IOANID, Doina op.cit.. See: http://www.observatorcultural.ro/Cit-de-pregatit-e-Sibiul-sa-fie-capitala-culturalaeuropeana-in-2007, articleID_16329-articles_details.html. [07/01/2015].

${ }^{47}$ RICHARDS, Greg, Rotariu, Ilie, op.cit, p. 7
} 
"Romania is not only a picturesque country with many problems" 48 , was considered by many "the first true image campaign of Romania" 49 . Both approaches at local and national levels led to strengthen the public confidence in governments that promote these principles, an argument in this respect being the recent election of Klaus Johannis Weber (mayor of Sibiu) as President of Romania.

- the program inspired local elites to increase the visibility of the city. An example of this is a group of 10 young people from Sibiu, businessmen, politicians, journalists, researchers and lawyers, who got together in the Association for City Beautification Sibiu, who decided to continue the efforts to promote and discover the city. Through own funds they arranged parks, funded social media promotion projects, providing information to people of different ages about local history and heritage ${ }^{50}$.

- understood together, the "Sibiu European Capital of Culture" was also a lesson for the local community, community that needed to learn how to "generate and manage large projects, but also to want to obtain this title, to work for it". The same community became at the same time more aware of how they relate to European culture and the ways in which it can accelerate the EU integration ${ }^{51}$.

If we now turn our attention to socio-economic indicators for measuring the program impact, we note that in the short and medium term the regional development was truly remarkable. As expected, the organization of major cultural events and increase revenue and boosts tourist arrivals in places adjacent to where events are organized ${ }^{52}$, but the overall

\footnotetext{
${ }^{48}$ In their approach, the central authorities took advantage of important visits and guests of the Sibiu: European Parliament President, Hans-Gert Pöttering Henri, Duke of the Grand Duchy of Luxembourg, Octavie Modert, Secretary of State in the Ministry of culture of Luxembourg, Crown Prince Frederik of Denmark, President of the Federal Republic of Germany, Horst Köhler, the forty-eight ambassadors of various countries around the world in Bucharest, the Ecumenical Patriarch of Constantinople Bartholomew IJose Manuel Barroso, European Commission President, Rene van der Linden, President of Parliamentary Assembly of the Council of Europe, Terry Davis, Secretary general of the Council of Europe, Jan Figel, Commissioner for culture, and Leonard Orban, Commissioner for Multilingualism.See: Doina Ioanid, op.cit. și Mădălina Cerban, op.cit.

${ }^{49}$ Ibidem (Material realized by Madalina Cerban, madalina.cerban@mediafax.ro)

${ }^{50}$ Official website of the "Association for the city's first documented Sibiu", http://aios.ro/despre-a-i-o-s/, accesat în 2.02.105 şi Maribela Tiron, „Cum a reuşit Sibiul, capitala europeană culturală din 2007, să atragă mai mulți turiști prin promovare pe rețelele sociale” in Ziarul Financiar, 13 septembrie 2014, http://www.zf.ro/companii/cum-a-reusit-sibiul-capitala-europeana-culturala-din-2007-saatraga-mai-multi-turisti-prin-promovare-pe-retelele-sociale-13257655. [07/01/2015].

51,"What advice is given Mayor of Sibiu to Cluj authorities in Cluj project -European capital of culture", interview given by Klaus Iohannis for Citynews, 1 october 2014, http://citynews.ro/cultura/ce-sfaturi-le-daprimarul-sibiului-autoritatilor-clujene-proiectul-cluj-capitala-culturala. [07/01/2015].

${ }_{52}^{2}$ RICHARDS, Greg, Rotariu, Ilie, op.cit, p. 10.
} 
impact of tourism depends on several factors: the scale of industry in the given location, the absolute number of visitors attracted, revenues in the area, the number of jobs created and the local physical transformations. Even in the medium term, tourism should generate employment, profit, tax payments and private investment ${ }^{53}$. Theories were confirmed by the "Sibiu European Capital of Culture" program, but the statistics and studies run by local researchers $^{54}$ demonstrate on the one hand, that investments in urban and cultural infrastructures materialized in the end in significant regional gains, and secondly, that due to the high number of tourists registered in 2007, the regional economic profitability increased, many companies registering significantly higher turnover compared to previous years:

- the economic profitability reported by companies in the tourism sector, compared to 2006 , was of $13.7 \%$ for tour operators, $10.9 \%$ for transport companies, $10.5 \%$ for hotels and motels, $8 \%$ for renting apartments, $7.9 \%$ for restaurants and bars

- $95 \%$ of hotels and guesthouses had a significant and higher financial impact;

- cash-wise, hotels recorded a net balance of $+80 \%,+75 \%$ tour operators and carriers $+75 \%$;

- many hotels were renovated and some promoted to a higher category, Sibiu is the only city in Romania which has received the maximum three star top rated in the Michelin Guide;

- new accommodation was built, many international brands are present in Sibiu in 2007 or in subsequent years ( Ramada, Hilton, Golden Tulip, Best Western, Ibis);

- accommodation capacity increased by $70 \%$ compared to 2005 , focusing on medium-sized and large hotels with more than 70 rooms. Thus by the end of 20096 new hotels were built with 3 or 4 stars; the pace registered some slowdown in 2010;

- Number of beds increased to 2200, as compared to 1320 recorded in 2005;

\footnotetext{
${ }^{53}$ BAKUCZ, Marta - European Capital of Culture on the Periphery, Documentation Centre on European Capitals of Culture, p. 2 at:

http://ecoc-doc-athens.eu/attachments/450_Bakucz,\%20M.\%20EUROPEAN\%20CAPITAL\%20O F\%20CULTURE\%20ON\%20THE\%20PERIPHERY.pdf. [07/01/2015].

${ }^{54}$ LUCA, Sabina-Adina, op.cit, p. 175 - 177; COSMA, Smaranda; NEGRUSA, Adina; POPOVICI, Cristina, op.cit, p. 71 - 72; OANCA, Alexandra, op.cit, p. 61; official site of Sibiu CCE 2007 Programme, http://www.sibiu2007.ro/ro3/bilant.htm; și Primăria Sibiu, „Sibiu - Hermannstadt în cifre”, http://www.sibiu.ro/ro2/pdf/2008/pliant_Primarie_Sibiu\%20_in_cifre.pdf. [07/01/2015].
} 
- Number of tourists (approx. 800.000) doubled up as compared to 2006 and tripled up as compared to 2005 . Out of these $40 \%$ were foreigners coming from countries like Germany, Luxemburg, Francea, Belgium, Austria, Italy, Spain and Great Britain.

- Number of visitors to museums doubled in 2007 ;

- more than 50\% of companies hired new staff in Sibiu in 2007, with an average of 3.3 persons per company;

- Companies reported a total of 930 new jobs in 2007;

- the average wage is higher than in other neighboring counties (323 euro in early 2008) and in terms of standard of living, Sibiu ranks 4 after Timis, Bucharest and Ilfov;

- about half of the inhabitants of Sibiu are active in industrial development: $49 \%$ in industry, $15 \%$ - trade, $7.5 \%$ - health , 7.5\%-construction, 7\%- education, $6.5 \%$-transport;

- unemployment in Sibiu is under the national average, the share of unemployed persons among people between the ages of 18 and 62 years was $0.8 \%$, while the unemployment rate registered in the year 2007 in Sibiu County was 3.6\%

- local City Hall budget revenues were bigger with $12 \%$, compared to 2006, with $84 \%$ from 2004

- due to the modernization of the airport, Sibiu has direct flights with cities and regions such as: Bucharest, Munich, Vienna, Stuttgart, Marseilles, Antalya, Tunis

- Sibiu is linked via Highway A1 from the Pan-European corridor IV

- Sibiu is one of the cities with the highest level of foreign investment in Romania, functioning near Bucharest the financial and Monetary Exchange of goods

- the industrial zone Sibiu-Șura Mică hosts big names of European industry: Continental Automotive Systems, Marquardt Schaltsysteme, Khunke Production, Brandl en, Takata, SNR Bearings, Gühring OHG, Bramac, Phoenix RUD Kettenfabrik Rieger \& Mechano Dietz, Pharmaceuticals, Medical Center MEWA, TAS, Siemens, Delphi, Grainer, Poliflex, KruppBilstein, Tondach, Winerberger. They conducted business in areas such as the 
automotive industry, building materials, industrial robots, moulds, plastics and pharmaceutical industry;

- investments have expanded to other urban centers adjacent to Sibiu: Mediaș, Cisnădie, Avrig, Miercurea Sibiului, Tălmaciu;

- GDP per capita recorded in the Sibiu County in 2006 was 4.976 lei

- Sibiu City Hall came to be mainly self-financing, $77 \%$ of the 2009 budget issued from fees of the investors in the industrial zone of the West. The contribution to the State budget, was in 2012, higher than any other County in Transylvania, Sibiu occupying 4th place by country

From a cultural standpoint, the program has changed the map of cultural attractions. If by 2007, a classic city tour included a walk downtown and visiting Brukenthal Museum and traditional events organized were limited to a few per year, in 2008 the cultural agenda became more connected to tourist flows with events organized throughout the year. Investments in new attractions (ASTRA, Lower Tower, Fortifications, Orthodox and Evangelical cathedrals) continued, which led to the constantly increasing number of visitors to museums and participants in events and shows. The new experience and ability to work in the community encouraged local authorities to launch a new project in 2012, Sibiu Baroque Update, addressing mainly the domestic market of tourists ${ }^{55}$. Festivals such as TIFF and Modern Dance, which had its first edition in 2007 in Sibiu continued in subsequent years with the support of the Ministry of Culture ${ }^{56}$. Sibiu International Theatre Festival became in 2013 the third in the world after the ones in Edinburgh and Avignon, with 70 participating countries, over 350 events in over 60 places to about 60,000 spectators daily and approx. 600,000 annually. Astra Film Festival in Sibiu is considered the most important documentary film festival in Central and Eastern Europe and the International Folklore Festival has become one of the most important in the world ${ }^{57}$.

\section{Conclusions}

"Sibiu European Capital of Culture 2007" was designed to provide equal opportunities for issues such as social inclusion and cohesion, education, promotion of cultural heritage and

\footnotetext{
${ }^{55}$ RICHARDS,Greg; ROTARIU, Ilie, op.cit, p. 10 - 11

${ }^{56}$ LUCA, Sabina-Adina, op.cit, p. 172

${ }^{57}$ ILIEȘIU, Sorin; BONDREA, Ion (coord.), op.cit., p. 13
} 
tourism or urban regeneration at all levels, through the center of local life culture. Improving the image of the city by renovating the historic center and a large number of monuments, accompanied by organizing high-class cultural events generated positive effects on the local community. The program utility on short and medium terms can be demonstrated if we look at the socio-economic outputs, as previously argued: increased visibility at European and international levels of Sibiu and Romania as a whole, in the year for the EU accession; historic German city development profile, part of the European cultural sphere, defined at national and international level; organizing various cultural events, some of which were repeated in subsequent years; substantial increase in the number of tourists, especially European ones; steady increase in the number of residents participating in cultural events; strengthen local identity and developing a sense of pride; improving urban infrastructure and cultural direct positive impact on the quality of life in the region; the development of cooperation with other European regions and promotion of cultural cooperation. Regarding the outcomes, they can be circumscribed in the same positive feature: increased confidence in the ability of local inhabitants to local government; increase in the sense of belonging to a national or local community that can rise to the expectations of the European Union; development of civic awareness and social responsibility; expertise gained from the implementation of such a program

The emphasis on architecture and common origins with other German communities in Europe led to the disadvantage of certain cultural institutions (ASTRA Museum Complex whose specificity does not fold on any topics of the program), or the population of the historic center or independent artists ${ }^{58}$. Mapping the events highlights a cultural agenda held in locations such as museums, churches and theaters in the city center, as the suburbs and surrounding areas were not prepared to be attractive to tourists or open to culturalization strategies. The character rather "exclusive than inclusive, in spatial terms" of the program emphasizes a "more conservative picture of cultural tourism" based on the assumption that cultural activities can be "found only in institutions and aesthetic places indicating historical truth". Not including local creative industries through means of urban and regional economic development, as well as failure to put together several non-profit groups and local associations ${ }^{59}$ are another two elements related to deficiencies in program implementation.

\footnotetext{
${ }^{58}$ OANCA, Alexandra, op.cit, p. 60

${ }^{59}$ HABIT, Daniel - Peripheral ECOCs between cultural policy and cultural governance: the case of Sibiu 2007." In PATEL, Kiran Klaus (ed.), The Cultural Politics of Europe. European Capitals of Culture and European Union since the 1980s, Routledge, 2013, p. 135 - 136
} 
However, Sibiu had many other important experiences that sketched the characteristics of a sustainable regional development: cooperation capacity superior to other urban areas; a public-private partnership balanced effectively in attracting European funds; rational distribution of investments between center and periphery, favorable decrease local disparities; harmonious interfaith and interethnic interactions ${ }^{60}$. From the statements of local and national authorities, given at the end of the program it is obvious that their intention was to materialize the accumulated expertise in: promoting high quality tourism experiences aware of the environment; satisfaction of tourists in relation to the experience so that they are willing to tell others; integration of tourism industry in a broader concept and its connection to a network of regional service quality; development of gastronomy and hotel industries complemented by an attractive calendar of cultural - art events ${ }^{61}$.

\section{Bibliography}

BAKUCZ, Marta - European Capital of Culture on the Periphery. S.1.: Institute of Economics and Regional Studies, Faculty of Business and Economics, University of Pécs, s.d.

BOROZAN, Dula - "Regional Competitiveness: Some Conceptual Issues and Policy Implications" [online] In Interdisciplinary Management Research, 2008, vol. 4. In http://www.efos.unios.hr/repec/osi/journl/PDF/InterdisciplinaryManagementResearchIV/IMR 4a03.pdf, [September, 1st, 2014].

COSMA, Smaranda; NEGRUSA, Adina; POPOVICI, Cristina, - "Impact of Sibiu European Capital of Culture 2007 event on country tourism.” In MASTORAKIS, Nikos E.; JHA, Manoj; MLADENOV, Valeri; BOJKOVIC, Zoran; KARTALOPOULOS, Stamatios (eds.) Recent Advantage in Cultural Heritage and Tourism. S.1.: WSEAS Press, 2009.

DORIN, Jula, Regional Economy, Editura Estfalia, Bucureşti, 2002.

\footnotetext{
${ }^{60}$ ILIEȘIU, Sorin; BONDREA, Ion (coord.), op.cit., p. 4

${ }^{61}$ VLADACENCO, Florian, op.cit.

http://www.vacantesicalatorii.ro/modules/revista/articole/articol.php?artID=1809. [07/01/2015].
} 
HABIT, Daniel, "Peripheral ECOCs between cultural policy and cultural governance: the case of Sibiu 2007.” In PATEL, Kiran Klaus (ed.) - The Cultural Politics of Europe. European Capitals of Culture and European Union since the 1980s. S.1.: Routledge, 2013.

HORGA, Ioan; BĂRBULESCU, Iordan Gheorghe; IVAN, Adrian - Regional and cohesion policy: insight into the role of the partnership principale in the new policy design. In Regional and cohesion policy. Oradea: Debrecen, 2011.

ILIEȘIU, Sorin; BONDREA, Ion (coord.) - Sibiu: regional capital. Objective arguments, “Lucian Blaga.” Sibiu: University Press, , 2013.

IMMLER, Nicole L.; SAKKERS, Hans - Programming Europe: European Capitals of Culture: rething the role of culture. In Journal of European Studies, vol 44 (I), 2014, p.5.

IOANID, Doina - "How prepared is the city of Sibiu to be European capital of culture in 2007.” In Aletheea, n. ${ }^{\circ} .342 /$ octomber 2006.

LAZZERETTI, Luciana - Creative Industries and Innovation in Europe. Concepts, Measures and Comparative Case Studies. S.1: Routledge, 2012, p.12.

LUCA, Sabina Adina - "The role of the programme Sibiu 2007-European capital of culture in socio-economic urban development." In Quality of Life, vol. XX, no. 1-2/2009, Romanian Academy Press, Bucharest, 2009.

MAZILU, Mirela, "Romania, Tourism and Culture - Major Drivers of Regional Attractiveness." In MASTORAKIS, Nikos; MLADENOV, Valeri et al (eds.) - Recent Researches in Mechanisc. S.1.: WSEAS Press, 2011.

MYERS, S. - Democracy is a Discussion. Civic Engagement in Old and New Democracies. Connecticut: The Handbook, Connecticut College, 1996, p. 7. 
OANCA, Alexandra, - Governing the European Capital of Culture and Urban Regimes in Sibiu. MA Thesis, Budapest: Central European University, Department of Sociology and Social Anthropology, 2010.

RICHARDS, Greg; ROTARIU, Ilie - "The Impact of Cultural Events on Tourism Development: Sibiu - the European Cultural Capital.” In Annals of the „Constantin Brâncuşi” University of Târgu Jiu, Economy Series, Issue 1/2013, “Academica Brâncuși”, Târgu Jiu: Publishing House, 2013.

TIRON, Maribela - "How succeded Sibiu, European cultural capital in 2007, to attract more tourists through promotion on social networks." In Ziarul Financiar, 13 septembrie 2014.

VASILIU, Florica; DRAGOMAN, Dragon - "Cultural policies and the affirmation of identity. Luxembourg and the Grand Region-Sibiu. European cultural capital 2007" in Romanian Sociology, vol. VI, no. 2/2008, Editura Polirom, Iaşi, 2008.

VLADENCO, Florian - "How the project of Sibiu European capital of Culture 2007 was born”, interview with Klaus Weber Iohannis. In Vacanțe și Călătorii.

\section{Web resources}

http://ec.europa.eu/dgs/regional_policy/index_ro.htm http://europa.eu/pol/pdf/flipbook/ro/regional_policy_ro.pdf http://ro.scribd.com/doc/57779774/Rolul-Valorilor-Culturale-in-Societate\#scribd http://www.capitalaculturala2021.ro/ceac2021_doc_2_actiunea-privind-capitalele-europeneale-culturii_pg_0.htm http://www.mdrap.ro/dezvoltare-regionala/politica-de-dezvoltare-regionala www.aios.ro www.citynews.ro www.mediafax.ro www.observatorcultural.ro www.sibiu.ro, official siteof Sibiu Cityhall www.sibiu2007.ro 